\title{
The Effects of Spiritual Intelligence and Organizational Citizenship Behavior to Employees Performance: Study at Sharia Banks in Gorontalo Province
}

\author{
Muhdar HM \\ Lecturer, Faculty of Economics and Islamic Business, State Islamic \\ Institute of Sultan Amai Gorontalo \\ email: muhdar@iaingorontalo.ac.id
}

\begin{abstract}
The employees' existence as an organizational locomotive need to get attention for management because, it is employees who make the organization perform well. Spiritual intelligence and organizational citizenship behaviour (OCB) are known to have effect for improving employee performance. To see this effect, then research was conducted at Sharia Bank in Gorontalo Province with the aim of analyzing and describing the effect of: spiritual intelligence on OCB, spiritual intelligence on employee performance, OCB on employee performance, and spiritual intelligence on employee performance through OCB. The findings of this study are spiritual intelligence had positive and significant effect on OCB. OCB has positive and significant effect on employee performance. Spiritual intelligence has positive and insignificant effect on employee's performance, but spiritual intelligence has positive and significant effect for employee performance through OCB.
\end{abstract}

Keywords: Spiritual Intelligence; organizational citizenship behavior; Performance

\begin{abstract}
Abstrak: Keberadaan karyawan sebagai lokomotif organisasi perlu mendapat perhatian oleh manajemen karena karyawan yang membuat organisasi berkinerja baik. Kecerdasan spiritual dan perilaku kewargaan organisasional (OCB) diketahui memiliki implikasi untuk meningkatkan kinerja karyawan. Untuk melihat implikasi ini, maka dilakukan penelitian pada Bank Syariah di Provinsi Gorontalo dengan tujuan menganalisis dan menggambarkan implikasi dari: kecerdasan spiritual terhadap OCB, kecerdasan spiritual terhadap kinerja karyawan, OCB terhadap kinerja karyawan, dan kecerdasan spiritual terhadap kinerja karyawan melalui OCB. Hasil penelitian menunjukkan bahwa kecerdasan spiritual memiliki implikasi positif dan signifikan terhadap OCB. OCB berimplikasi positif dan signifikan terhadap kinerja karyawan. Kecerdasan spiritual berimplikasi positif dan tidak signifikan terhadap kinerja karyawan, tetapi kecerdasan spiritual berimplikasi positif dan signifikan terhadap kinerja karyawan melalui OCB.
\end{abstract}

Kata Kunci: kecerdasan spiritual; perilaku kerwargan organisasional; kinerja karyawan

Economica: Jurnal Ekonomi Islam - Volume 9, Nomor 2 (2018) 


\section{Introduction}

Organizational citizenship behaviour (OCB) or behaviour characterized by voluntary initiatives that prosocial contributions to organizations and coworkers, working above formal employment and outside formal employment roles, are increasingly important in the organizational context. OCB is a behavior of discretionary person's that is not explicitly recognized because of formal reward system, and in aggregate encourages more effective organizational functions (Organ 1988). OCB is an employee behaviour that aims to increase the effectiveness of company performance without ignore the productivity goals of individual employees. That is why OCB is considered a factor that takes an important role in improving of employee and organizational performance.

One of the topics considered by sociologists and psychologists who can influence OCB is spiritual intelligence. Spiritual intelligence is intelligence that put behaviour and our life in the meaning context of broader and richer, intelligence to evaluate that one's actions or way of live more meaningful than others (Zohar and Marshall 2001), intelligence that can facilitate the resolution of everyday problems to achieve goals (Emmons 2000b).

Empirically, several studies have found that spiritual intelligence is positively related to OCB (Doostar, Chegini, and Pourabbasi 2012), to employee performance, and between OCB and employee performance. Meanwhile according to Anwar, Osman-Gani, and Osman-Gani (2015) that the dimensions of spiritual intelligence critical existential thinking and transcendental awareness have a large effect with OCB compared to the dimensions of personal meaning production and conscious state expansion. This component makes employees look for valuable work and create a favorable work environment to encourage creativity and aptitude for selfdevelopment (Doostar, Chegini, and Pourabbasi 2012). Organizational managers must prepare the right work environment and improve the 
workplace spirituality if they want to engage employees with OCB behavior. Thus intelligent people of spiritually engage in extra-role behavior (Rashvand and Bahrevar 2013). However, not all studies of spiritual intelligence with OCB produce the same findings. Like research by Yadav and Punia (2016) found that spiritual intelligence unsignificant effect on OCB. The difference between the findings of the researchers made spiritual intelligence in relation to OCB interesting to be examined until now.

The empirical phenomenon of spiritual intelligence described above raises pros and cons, but it is theoretically believed that it can influence the formation of employee OCB and impact on improving employee performance at each of organization, including the Sharia Banking sector in Gorontalo Province. The study of this phenomenon is relevant and needs be applied to Syariah Banks, especially spiritual intelligence and OCB variable. Because spiritual intelligence will develop well if it is supported by strong Islamic values, while OCB theory is relevant to the values taught in Islam, namely the values of sincerity, taawun, ukhwah, mujahadah. In the efforts to increase the Sharia Banks employees performance, of course will be greatly influenced by the employees behavior. Various views and efforts have been applied increase the Sharia Bank employees performance, but it is believed that everything will not be separated and must be preceded by efforts to consistently grow the spiritual intelligence of employees well.

Thus, to see the spiritual intelligence and OCB impact to employee performance, it is necessary to analyze the Sharia Banking sector in the Gorontalo Province. Sharia banking was chosen as the place for this research, because in addition to applying sharia principles or spirituality values, also that the phenomenon of the development of sharia banks in Indonesia continues to grow. At present, the number of sharia banks is 196 units, consisting of 13 Sharia Commercial Bank (BUS), 23 sharia business units (UUS), and 160 Sharia People's Credit Banks (BPRS) which spread throughout the provinces in Indonesia including Gorontalo Province. Sharia 
Muhdar HM

Banking in Provinsi Gorontalo consists of 2 (two) Branch Offices, 2 (two) Sharia Services Units, and 1 (one) cash office with total financing based on Usage Type in December 2017 of 271 (Billion IDR). In detail, Sharia Banking financing in Indonesia based on the type of usage detailed in table 1 below:

Table 1. Financing based on Type of Usage, Debtors Groups and Region of BUS and UUS Billion IDR

\begin{tabular}{lcccc}
\hline \multicolumn{1}{c}{ Province } & Modal Kerja & Investasi & Konsumsi & Total \\
\hline Jawa Barat & 9.591 & 5.232 & 16.853 & 31.676 \\
\hline Banten & 1.645 & 885 & 5.149 & 7.679 \\
\hline DKI Jakarta & 52.704 & 37.824 & 32.671 & 123.199 \\
\hline D.I Yogyakarta & 706 & 869 & 1.599 & 3.174 \\
\hline Jawa Tengah & 7.220 & 3.816 & 5.884 & 16.920 \\
\hline Jawa Timur & 10.501 & 4.270 & 9.576 & 24.347 \\
\hline Bengkulu & 180 & 230 & 598 & 1.008 \\
\hline Jambi & 459 & 518 & 1.510 & 2.487 \\
\hline Aceh & 1.427 & 283 & 12.316 & 14.026 \\
\hline Sumatera Utara & 3.024 & 2617 & 4.341 & 9.982 \\
\hline Sumatera Barat & 844 & 455 & 2.319 & 3.618 \\
\hline Riau & 819 & 1339 & 3.038 & 5.196 \\
\hline Sumatera Selatan & 1249 & 1214 & 3.007 & 5.470 \\
\hline Bangka Belitung & 69 & 35 & 306 & 410 \\
\hline Kepulauan Riau & 302 & 979 & 2.477 & 3.758 \\
\hline Lampung & 1059 & 544 & 968 & 2.571 \\
\hline Kalimantan Selatan & 1599 & 1415 & 1.866 & 4.880 \\
\hline Kalimantan Barat & 1091 & 986 & 2.018 & 4.095 \\
\hline Kalimantan Timur & 1385 & 769 & 2.360 & 4.514 \\
\hline Kalimantan Tengah & 174 & 449 & 567 & 1.190 \\
\hline Sulawesi Tengah & 166 & 103 & 971 & 1.240 \\
\hline Sulawesi Selatan & 1560 & 968 & 3.321 & 5.849 \\
\hline Sulawesi Utara & 78 & 53 & 324 & 455 \\
\hline & & & & \\
\hline & & & & \\
\hline
\end{tabular}


The Effects of Spiritual Intelligence and Organizational...

\begin{tabular}{lcccc}
\hline \multicolumn{1}{c}{ Province } & Modal Kerja & Investasi & Konsumsi & Total \\
\hline Gorontalo & $\mathbf{3 8}$ & $\mathbf{1 6}$ & $\mathbf{2 1 7}$ & 271 \\
\hline Sulawesi Barat & 11 & 9 & 209 & 229 \\
\hline Sulawesi Tenggara & 170 & 123 & 691 & 984 \\
\hline Nusa Tenggara Barat & 634 & 259 & 2.138 & 3.031 \\
\hline Bali & 350 & 274 & 1.000 & 1.624 \\
\hline Nusa Tenggara Timur & 48 & 10 & 99 & 157 \\
\hline Maluku & 6 & 9 & 137 & 152 \\
\hline Papua & 159 & 92 & 237 & 488 \\
\hline Maluku Utara & 62 & 26 & 166 & 254 \\
\hline Papua Barat & 31 & 24 & 89 & 144 \\
\hline Outside Indonesia & 463 & 153 & 0 & 616 \\
\hline \multicolumn{1}{c}{ Total } & $\mathbf{9 9 . 8 2 5}$ & $\mathbf{6 6 . 8 4 8}$ & $\mathbf{1 1 9 . 0 2 1}$ & $\mathbf{2 8 5 . 6 9 4}$ \\
\hline
\end{tabular}

Source: Otoritas Jasa Keuangan Republik Indonesia (2017)

Based on Table 1, the total financing in 2017 amounted to 285,694 (billion IDR). This financing is managed with a number of employees who continue to grow from year to year, as in table 2 below:

Table 2. Total Number of Employees in Indonesia, 2014 - 2017

\begin{tabular}{lcccc}
\hline Sharia Banking & $\mathbf{2 0 1 4}$ & $\mathbf{2 0 1 5}$ & $\mathbf{2 0 1 6}$ & $\mathbf{2 0 1 7}$ \\
\hline BUS & 41.393 & 51.413 & 51.110 & 52.142 \\
\hline UUS & 4.425 & 4.403 & 4.487 & 4.452 \\
\hline BPRS & 4.704 & 5.102 & 4.372 & 4.619 \\
\hline Total & $\mathbf{5 0 . 5 2 2}$ & $\mathbf{6 0 . 9 1 8}$ & $\mathbf{5 9 . 9 6 9}$ & $\mathbf{6 1 . 2 1 3}$
\end{tabular}

Source: Otoritas Jasa Keuangan Republik Indonesia (2017)

Based on table 2 above, there were 61,213 employees in 2017, including 67 employees of Gorontalo Province Islamic banking which also became the unit of analysis of this study with the problem formulation of how are the spiritual intelligence and OCB effect to Sharia Banks employees performance in Gorontalo Province?

Economica: Jurnal Ekonomi Islam - Volume 9, Nomor 2 (2018)

http://journal.walisongo.ac.id/index.php/economica 
Muhdar HM

\section{Literature Review}

\section{Spiritual Intellegence}

According to King and DeCicco (2009) that spiritual intelligence is a mental capacity rooted in non-material and transcendental aspects of facts and reality, in his statement that the definition of spiritual intelligence is a intellectual capacities set that contribute to adaptive awareness, integration, and application in non-material and transcendent aspects of one's existence which leads to results like visceral existential reflection, increased meaning, recognition of self-transcendence, and master spiritual conditions (King and DeCicco 2009). Spiritual intelligence involves a set of abilities that utilize spiritual resources (Emmons 2000a, 2003) Spiritual intelligence is the intelligence to place our behavior and life in the wider context and richer meaning, intelligence to judge that the actions or someone's way of life is more than others (Zohar and Marshall 2001).

King and DeCicco (2009) measure spiritual intelligence through four dimensions, namely: First, Critical Existential Thinking (CET). Is the capability to critically contemplate meanings, goals, and existential problems or other metaphysical (for example, reality, cosmos, chamber, time, dead). Second, Personal Meaning Production (PMP). Is the capability to develop meaning and purpose of personal for each physical and mental experiences, including the capability to make and master life goals. Like existential thinking, personal meaning is often described as a component of spirituality requiring consideration in the model of spiritual intelligence. Third, transcendental awareness (TA). Is the capability to see diminsion of transcendent self (for example, transcendent self), others, and from the physical world (for example, non-materialism, interconnectedness) during normal, building states of consciousness. Fourth, the Conscious state expansion (CSE). Is the capability get into consciousness of higher level; achieve an understanding of consciousness of pristine, consciousness of 
cosmic, entity, Oneness; for example through contemplation, meditation, prayer, rituals of worship

\section{Organizational Citisenship Behavior}

Bateman \& Organs in the 1980s introduced the concept of organizational citizenship behaviour (OCB) which was later refined by a number of researchers like Podsakoff and Mackenzie et al, Jahangir et al, and Rasgar et al, and others. The concept of OCB is in fact that OCB contributes to improving organizational effectiveness. Organizations will be effective when employees work not only on the job description but also works outside of its role and can even help fellow workers to achieve organizational goals. OCB is discretionary behavior, in a formal reward system not directly recognized and in an aggregate increase the effectiveness of organizational functions (Organ 1988).

OCB is an employee's spontaneous initiative, OCB can be promoted in the workplace through motivation of employee, and provide employees the chance to perform OCB by creating conducive work environment. This is one way to support of OCB. Therefore, management must be educated about OCB, and considerably to apply OCB in employee's performance assessment. This way could encourage the formation of OCB among employee (N. P. Podsakoff et al. 2009).

Based on the taxonomic dimensions of OCB from Organ (1988) introduced the construct of OCB into two parts, namely: OCB-I (individual's personality, consisting of altruism and courtesy) and OCB-O (directed behavior in the organization, which consists of conscientiousness, civic virtue, sportsmanship). Altruism describes behaviour which is intend to help a particulary people. Conscientiousness shows behavior that gives a role far beyond the minimum level required.

Sportsmanship shows the behaviour involved when someone receives frustration without complaint. Courtesy shows action taking behaviour to 
prevent problems from being gained by respecting the wishes and desires of others. Civic Virtue shows behavioural behaviour designed to increase one's participation and support from the whole organization (Chahal and Mehta 2010).

\section{Performance}

In general, the most widely used performance theory is the theory of Campbell, McHenry, and Wise (1990). In a psychological aspect, Campbell explains that job performance is a personal performance. It means that job performance which is done by one person. Job Performance is part of behaviors in their work that are relevant to the purpose of the organization. Performance consists of behaviors that employees can really engage in that can be observed (Rastgar et al. 2012). Performance is a employee's behaviour which can be observed by someone (Rastgar et al. 2012). Performance is the use of effective and efficient resources to achieve results (Berman and Berman 2006). The meaning of effectiveness is the level of results where it is also as achievements or success rates. While efficiency is the ratio of output (outcome) and input. This describes the cost per activity to achieve the results provided. Efficiency is the ratio of resources used (input) to achieve achievement (outcome or output) (Berman and Berman 2006). Rafferty and Griffin (2004) describes that job performance is one of the total collections of work at workplace. Thus, job performance could be described as the effect that is received by one's business with their abilities in certain circumstances (Yadav and Punia 2013).

In accord with Mathis and John H. (2006), performance elements generally consist of five elements, namely: (1) quality of results; (2) quantity of results; (3) timeliness; (4) attendance; and (5) the ability to work together. Becker et al. (1996), in his research used six performance indicators, namely: (1) completing work in a timely and effective manner, (2) doing high-quality work, (3) completing tasks in a satisfying way, (4) quality of work, (5) 
quantity of work, and (6) overall performance. Then he refined it to: (1) quality of work, (2) quantity of work, (3) attitude, (4) cooperation, (5) communication, and (6) overall performance. Meanwhile, according to Wirawan (2009) one of the performance indicators is the personal nature that has been done in workplace. A person has many personal traits that are brought from birth and are acquired as adults from work experience. Personal characteristics that are judged are only personal characteristics related to work, for example: appearance, attitude towards work, honesty, smartness, creativity and so on.

\section{Conceptual Framework and Research Hypothesis}

Organizational citizenship behaviour was initially conceptualized as extra-role behaviour that is valued by the organization but in the formal reward system not explicitly recognized, and leader-member exchange. This is a model offered for the effectiveness of the functions of new forms of organization. Katz identifies three employee behaviours that are important for the effectiveness of the organization, namely entering and staying in the organization as employees; perform special roles as needed; and are bound to innovative and spontaneity or unplanned activities that are outside the role performed (Konovsky and Pugh 1994). This third behaviour is called OCB which is a behaviour that is not directly valued in the formal reward system in the organization. This behaviour is considered important because it is not standardized, but influential in assessing the performance and effectiveness of the organization (P. M. Podsakoff, Ahearne, and MacKenzie 1997). In several studies, there is a significant relationship between the OCB component and performance. The partially, OCB components (conscientiousness, altruism, citizenship virtue, generosity, respect) significant relationship with all performance indices like performance job behaviours and development (Khazaei, Khalkhali, and Eslami 2011). Organizations that have a good OCB will perform better than other 
organizations (Robbins 2008). Similarly, the findings of Rastgar et al. (2012) that OCB has a significant effect on employee performance. When employees behave extra roles, work performance also increases.

The spiritual intelligence position in shaping OCB and its implications in increasing employee performance is important, because spiritual intelligence contains several aspects that are spiritual intelligence characteristic, namely: hospitality, closeness, curiosity, creativity, construction, self-mastery, and religious. This intelligence that we use not only to know the values that exist, but also to creatively find new values (Zohar and Marshall 2001). Spiritual Intelligence in relation to OCB according to (Rastgar et al. 2012; Doostar, Chegini, and Pourabbasi 2012; Rashvand and Bahrevar 2013; Muhdar et al. 2015) is positively related.

Spiritual intelligence components such as Critical Existential Thinking (CET), personal meaning production (PMP), transcendental awareness (TA) and Conscious state expansion (CSA) are related to OCB (Doostar, Chegini, and Pourabbasi 2012). this component makes employees look for valuable work and invent of work environment to drive creativity and flair for their development. (Doostar, Chegini, and Pourabbasi 2012), Critical Existential Thinking is the capability to understand the existence of nature and the nonexistential things that lie behind it; Personal Meaning Production is the capability to interpret of physical and psychological experiences, including formulating life goals; Transcendental Awareness is the capability to understand the dimension of transcendent from oneself, others, and the physical world in non-materialistic understanding; Whereas Conscious State Expansion is the capability to enter a higher level of consciousness; achieve an understanding of pristine consciousness, consciousness of cosmic, unity, Oneness; for example through contemplation, meditation, prayer, ritual worship (King and DeCicco 2009).

Rastgar et al. (2012) explained that the importance of spiritual intelligence of employees in the organization so that organizational 
managers must make the right environment and improve spirituality at work if they want to involve employees who behave OCB. Even explicitly explained that intelligent people of spiritually will engage in extra-role behaviour (Rashvand and Bahrevar 2013). Therefore, organizations must afford to supply stimulation to their employees to empower the spiritual intelligence potential of organizational employees (Muhdar 2015).

The spiritual intelligence and performance relationship theoretically will provide an achievement for someone (Tisler, Biberman, and McKeage 2002). This discovery is very important as a basis for further research. This means there is a direct relationship between spiritual intelligence and performance. McGhee and Grant (2008) in a socio-cultural perspective that spiritual intelligence influences organizational achievement. This is caused by spiritualism in the workplace will bring improvements to one's ethics and will also affect the culture in a company. Based on some literature, McGhee and Grant (2008) say that a person's spirituality will be characterized by special traits and the life of self-transcendence, interconnectedness, awareness of goals and beliefs into the ultimate concern. The properties and life are called ideal regulative. Ideal regulation will affect moral values which are spiritual essence. Moral values become good (virtue) and practical wisdom (McGhee and Grant 2008). These values will also affect the company's climate and will benefit the achievement of the organization (Hanafi 2010). Several empirical studies show that performance / productivity increases due to spirituality at work (Javanmard 2012). In addition, spirituality has been shown to reduce stress (Kumar and Pragadeeswaran 2011), and reduce depression (Miller et al. 2012). Schematically the relationship between variables described above can be arranged as follows. 
Figure 1. Conceptual Framework Model

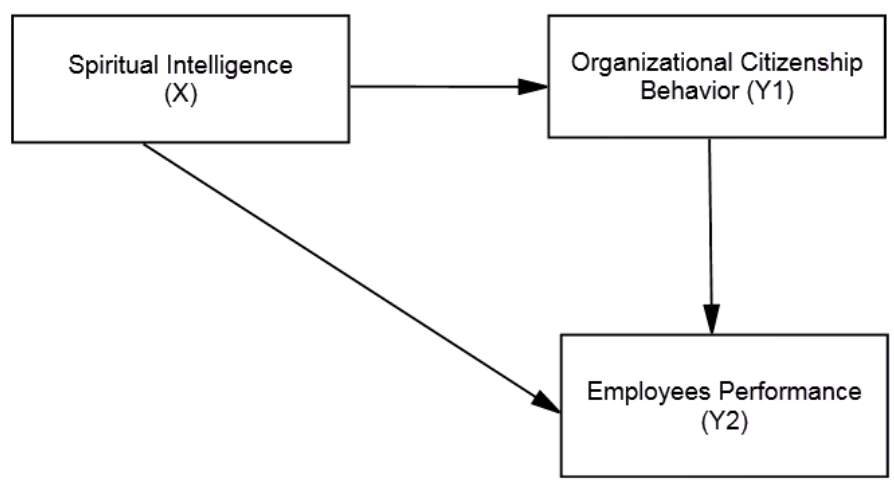

Based on the conceptual framework model at figure 1 above, the regression equation that is formed is:

$$
\begin{aligned}
& Y_{1}=\alpha_{0}+\alpha_{1} X+e_{1} \\
& Y_{2}=\beta_{0}+\beta_{1} X+\beta_{2} Y_{1}+e_{2}
\end{aligned}
$$

Based on the theoretical concepts and conceptual framework above, the research hypothesis is:

H1: Spiritual intelligence has positive and significant effect to organization citizenship behavior of Sharia bank in Gorontalo Province.

H2: Spiritual intelligence has positive and significant effect to employee's performance of Sharia Bank in Gorontalo Province.

H3: Organizational citizenship behavior has positive and significant effect to employee performance of Sharia Banks in Gorontalo Province. 
The Effects of Spiritual Intelligence and Organizational...

H4: Spiritual intelligence has positive and significant effect to employee performance through organizational citizenship behavior intervening variables of Sharia Banks in Gorontalo Province.

\section{Research Methods}

Respondent The number of respondent in this study were 67 employees which included 31 employees from Indonesia Muamalat Bank of Gorontalo Branch and 36 employees from the Mandiri Syariah Bank of Gorontalo Branch.

Dimensions and Measurement Scale. Dimensions and measurement scale of used to each variable measure are explained as table 3 below.

Table 3. Dimension and Variables Measurement Scale

\begin{tabular}{|c|c|c|}
\hline Variable & $\begin{array}{c}\text { Dimensions (King and } \\
\text { DeCicco, 2009) }\end{array}$ & Measurement Scale \\
\hline \multirow{2}{*}{$\begin{array}{l}\text { Spiritual } \\
\text { Intelligence }\end{array}$} & Personal Meaning Production (PMP) & 1 - 5 (Very Disagree - Very Agree) \\
\hline & Transcendental Awareness (TA) & 1 - 5 (Very Disagree - Very Agree) \\
\hline \multirow[t]{2}{*}{$(\mathrm{X})$} & Conscious State Expansion (CSE) & 1 - 5 (Very Disagree - Very Agree) \\
\hline & Critical Existential Thinking (CET) & 1-5 (Very Disagree - Very Agree) \\
\hline Variable & Dimensions (Organ, 1988) & Measurement Scale \\
\hline \multirow[t]{5}{*}{$\mathrm{OCB}(\mathrm{Y} 1)$} & Altruism & 1 - 5 (Very Disagree - Very Agree) \\
\hline & Conscientiousness & 1 - 5 (Very Disagree - Very Agree) \\
\hline & Sportsmanship & 1-5 (Very Disagree - Very Agree) \\
\hline & Courtesy & 1 - 5 (Very Disagree - Very Agree) \\
\hline & Civic virtue & 1-5 (Very Disagree - Very Agree) \\
\hline Variable & $\begin{array}{l}\text { Dimensions (Muhdar et al, } \\
\text { 2015) }\end{array}$ & Measurement Scale \\
\hline \multirow{6}{*}{$\begin{array}{l}\text { Employees } \\
\text { Performance }\end{array}$} & Work quality & 1 - 5 (Very Disagree - Very Agree) \\
\hline & Work quantity & 1 - 5 (Very Disagree - Very Agree) \\
\hline & Punctuality & 1 - 5 (Very Disagree - Very Agree) \\
\hline & Initiative & 1 - 5 (Very Disagree - Very Agree) \\
\hline & Teamwork & 1-5 (Very Disagree - Very Agree) \\
\hline & Personal Attitudes Toward Work & 1 - 5 (Very Disagree - Very Agree) \\
\hline
\end{tabular}

Economica: Jurnal Ekonomi Islam - Volume 9, Nomor 2 (2018) 
Muhdar HM

Validity and Reliability Testing. Validity test focuses on construct validity (content and meaning of a concept from the measuring instrument used to measure the concept). Validity test using the help of SPSS for windows version 23. Valid or not an instrument will be listened to in the coefficient value $(r)$ at a significance level of 0.05 . If the correlation coefficient shows a significance level of less than 0.05 , the instrument is declared valid. Based on the validity test in the questionnaire for each variable for 30 respondents (pre-test) shows that all correlation items have a significance smaller than 0.05 . This means that the instrument in this study is declared valid.

While reliability testing is intended to listen to how far the stability, accuracy and homogeneity of the measuring instrument used. The instrument reliability can be seen through the Crobach Alpha statistical test. The instrument will be reliable if giving a crombach alpha value greater than 0.60 (Nunnally and Bernstein 1994). Based on the reliability test that the crombach alpha value of each variable is greater than 0.740 . Thus, the crombach alpha value greater than 0.6 . This means that each instrument is declared reliable.

\section{Results}

To find out and analyze the implications of spiritual intelligence and organizational citizenship behavior on employee performance, then used path analysis. Following are the results of regression analysis between variables Based on table 4, the regression equation $Y_{1}=2.005+0.503 \mathrm{X}$ is obtained. This equation means that assuming a constant value of 2.005 , then if spiritual intelligence $(X)$ increases one unit, then organizational citizenship behavior $\left(\mathrm{Y}_{1}\right)$ will increase by 0.503 or it can be said that organizational citizenship behavior will change by 0.503 every one unit of spiritual intelligence. 
The Effects of Spiritual Intelligence and Organizational...

Table 4. Results of Simple Regression Analysis

\begin{tabular}{lcccccc}
\hline $\begin{array}{l}\text { Criterion Variables } \\
\rightarrow\end{array}$ & \multicolumn{7}{l}{ Organisational citizenship behaviours (OCB) } \\
\hline Predictor variable & \multicolumn{7}{l}{ Unstandardized Coefficients } \\
\cline { 2 - 7 } & $\mathbf{B}$ & $\begin{array}{c}\text { Std. } \\
\text { Error }\end{array}$ & $\mathbf{t}$ & Sig. & $\mathbf{R}$ & $\mathbf{R}$ \\
\hline Constant & 2.005 & 0.393 & 5.104 & 0.000 & & \\
\hline $\begin{array}{l}\text { Spiritual } \\
\text { Intellegence }\end{array}$ & 0.503 & 0.097 & 5.162 & 0.000 & 0.575 & 0.330 \\
\hline
\end{tabular}

Meanwhile, correlation coefficient $\mathrm{R}=0.575$, can be interpreted that relationship of spiritual intelligence $(\mathrm{X})$ with organizational citizenship behaviour $\left(\mathrm{Y}_{1}\right)$ is a moderate. While the determination value of $\mathrm{R}$ Square $=$ 0.330 (33.5\%), can be interpreted that the spiritual intelligence contribution to organizational citizenship behaviour is $33.0 \%$ and the rest is influenced by other factors not investigated by researchers by $67.0 \%$.

Furthermore, to find out and analyze the effect of spiritual intelligence $(\mathrm{X})$ and organizational citizenship behavior $\left(\mathrm{Y}_{1}\right)$ on employee performance $\left(\mathrm{Y}_{2}\right)$, then used a multiple regression analysis. The following are multiple linear regression data.

Table 5. Results of Multiple Regression Analysis

\begin{tabular}{|c|c|c|c|c|c|c|c|c|}
\hline \multirow{3}{*}{$\begin{array}{l}\text { Criterion } \\
\text { Variables } \rightarrow \\
\text { Predictor } \\
\text { variable }\end{array}$} & \multicolumn{8}{|c|}{ Employee Performance } \\
\hline & \multicolumn{8}{|c|}{ Unstandardized Coefficients } \\
\hline & B & $\begin{array}{l}\text { Std. } \\
\text { Error }\end{array}$ & $\mathbf{t}$ & Sig. & $\mathbf{R}$ & $\begin{array}{c}\mathbf{R} \\
\text { Square }\end{array}$ & $\mathbf{F}$ & Sig \\
\hline Constant & 1.903 & 0.550 & 3.460 & 0.001 & 0.483 & 0.234 & 8.077 & 0.001 \\
\hline $\begin{array}{l}\text { Spiritual } \\
\text { Intellegence }\end{array}$ & 0.158 & 0.137 & 1.154 & 0.254 & & & & \\
\hline $\mathrm{OCB}$ & 0.389 & 0.157 & 2.487 & 0.016 & & & & \\
\hline
\end{tabular}

Based on the data in table 5 obtained the regression equation as follows: $\mathrm{Y}_{2}=1.903+0.158 \mathrm{X}+0.389 \mathrm{Y}_{1}$. This equation can mean that:

Economica: Jurnal Ekonomi Islam - Volume 9, Nomor 2 (2018) 
1. If spiritual intelligence $(X)$ and organizational citizenship behavior $\left(\mathrm{Y}_{1}\right)$ are constant, then the value of employee performance $\left(\mathrm{Y}_{2}\right)$ will change by a constant value of 1.903 .

2. If organizational citizenship behavior $\left(\mathrm{Y}_{1}\right)$ is constant and spiritual intelligence $(X)$ increases by one unit, then the employee's performance $\left(\mathrm{Y}_{2}\right)$ will increase by 0.158 , or in other words, the value of employee's performance $\left(\mathrm{Y}_{2}\right)$ will change by 0.158 every one unit of spiritual intelligence $(\mathrm{X})$

3. If spiritual intelligence $(X)$ is of constant value and organizational citizenship behavior $\left(\mathrm{Y}_{1}\right)$ has increased by one unit, then the performance of employees $\left(\mathrm{Y}_{2}\right)$ will increase by 0.389 or in other words the value of employee performance $\left(\mathrm{Y}_{2}\right)$ will change by 0.389 per one unit of organizational citizenship behavior $\left(\mathrm{Y}_{1}\right)$

Furthermore, the correlation coefficient value $\mathrm{R}=0.483$, can be interpreted that there is a moderate relationship between the spiritual intelligence variables $(\mathrm{X})$ with organizational citizenship behaviour $\left(\mathrm{Y}_{1}\right)$ on employee performance variables $\left(\mathrm{Y}_{2}\right)$. Meanwhile, determination value of $\mathrm{R}$ Square $=0.330(33.5 \%)$ can be interpreted that the spiritual intelligence and organizational citizenship behaviour contribution to employee performance is $33.0 \%$ and the rest is influenced by other factors not investigated by researchers by $67.0 \%$.

\section{Hypothesis Testing}

Hypothesis testing is carried out to prove the positive implications and significance of each independent variable on the dependent variable, both partially and simultaneously. Partial effect was carried out using the test while the simultaneous effect used the F test. Based on the data in Table 4 and 5 that: 
1. The data in table 4 shows that the probability value (sig) is 0.000 this value is less than 0.05 , which means that the spiritual intelligence variable $(X)$ has positive and significant implications for organizational citizenship behavior $\left(\mathrm{Y}_{1}\right)$

2. The data in table 5 shows that the probability value (sig) is 0.254 . This value is greater than the value of 0.05 . This means that spiritual intelligence $(\mathrm{X})$ does not have significant effect for employee performance (Y2).

3. The data in table 5 shows that the probability value (sig.) Is 0.016 . This value is smaller than 0.05 , which means that organizational citizenship behavior (Y1) has positive and significant implications for employee performance (Y2).

4. The data in table 5 shows that the probability value (sig) is 0.001 . This value is less than 0.05 . This means that spiritual intelligence $(X)$ and organizational citizenship behavior (Y1) simultaneously have positive and significant implications for employee performance (Y2).

The effect of spiritual intelligence $(\mathrm{X})$ variable on employee performance $\left(\mathrm{Y}_{2}\right)$ through organizational citizenship behavior $\left(\mathrm{Y}_{1}\right)$ variable is calculated through the following equation.

$$
\begin{aligned}
& Y_{1}=\alpha_{0}+\alpha_{1} X+e_{1} \\
& Y_{2}=\beta_{0}+\beta_{1} X+\beta_{2} Y_{1}+e_{2} \\
& Y_{2}=\beta_{0}+\beta_{1} X+\beta_{2}\left(\alpha_{0}+\alpha_{1} X+e_{1}\right)+e_{2} \\
& Y_{2}=\beta_{0}+\beta_{1} X+\beta_{2} \alpha_{0}+\beta_{2} \alpha_{1} X+\beta_{2} e_{1}+e_{2} \\
& Y_{2}=\beta_{0}+\beta_{2} \alpha_{0}+\left(\beta_{1}+\beta_{2} \alpha_{1}\right) X+\left(\beta_{2} e_{1}+e_{2}\right)
\end{aligned}
$$

So the indirect implication of spiritual intelligence $(\mathrm{X})$ on employee performance $\left(Y_{2}\right)$ is $\beta_{2} \alpha_{1}=0.389 \times 0,503=0,196$. This means that spiritual 
Muhdar HM

intelligence $(X)$ implication on employee performance $\left(Y_{2}\right)$ through organizational citizenship behavior $\left(\mathrm{Y}_{1}\right)$ is 0.196

\section{Discussion}

Experts integrate the essence of intelligence in some parts of human behaviour, one of which is spiritual intelligence. Spiritual intelligence is the intelligence to place our behavior and life in the relationship of broader and richer meanings, intelligence to judge that one's actions or ways of life are more valuable than others. Based on Table 4, spiritual intelligence has positive and significant implications for citizen organizational behaviour (OCB). This shows that spiritual intelligence an important role in determining the height or low of OCB. The better the spiritual ability of an employee, the better the OCB in the organization. Conversely if spiritual intelligence is low, employee OCB is also low.

This finding is theoretically in line with the view that OCB depends on the level of the employee's spiritual intelligence. OCB is a type of ultra-role behaviour and does not consider of material aspects and voluntary behaviour. Apparently, spirituality provides space for OCB in the context that people in this space can give meaning to their tasks and activities, because their relationship with meaning, value and so on can occur outside the role or OCB (Vares 2009). Spirituality is one of the main causes of OCB (Fatahi 2007). In addition, several studies that are in line with this research include (Muhdar et al. 2015); Rashvand and Bahrevar (2013), who in principle argue that spiritual intelligence and Organizational Citizenship Behaviour are positively and significantly related. Every spiritual intelligence component has a relationship with OCB (Muhdar et al. 2015).

Therefore, organizations are faced with employees who have the motive to find meaningful work, drive creativity and flair for their development. So, like a new approach, where the organization is encouraged to create a work environment that can improve spirituality, generate the power of creativity 
and self-growth of employees. Similarly, Rashvand and Bahrevar (2013) explained that spiritually intelligent people will be embroiled in extra-role behaviour. Therefore, organizational managers can design questionnaires that are appropriate for measuring the level of spiritual intelligence of employees; contribution to recruiting the most spiritually intelligent personnel. Furthermore, organizational managers must pay attention to improving the spiritual intelligence of their personnel. Therefore, in training practice, they must pay attention to the dimensions and concepts of spiritual intelligence, which help employees to engage in organizational citizenship behaviour.

The analysis results through multiple regression shows that spiritual intelligence has positive implications but not significant for employee performance. This finding, supports the findings by Dharmanegara et al., (2013) that spiritual intelligence unsignificant effect on employee performance unless mediated by religious values. This means that spiritual intelligence will not implicated on employee performance without the existence of religious values as a mediating variable that correlates with employee performance.

Muhdar et al. (2015) spiritual intelligence unsignificant effect on employee performance without mediating organizational citizenship behaviour. Spiritual intelligence is believed to be the highest intelligence, which is used to generate meaning and value. Referring to the motivation theory proposed by Maslow, spiritual intelligence is something that is related to self-actualization which is the highest-level motivation. The high spiritual intelligence in a person is characterized by growth and continuous transformation to achieve a balanced life between career/work and personal/family, and a feeling of joy and satisfaction that is realized by producing positive contributions to the surrounding environment. This fact is believed not to be fully felt by employees, because the results of the study 
Muhdar HM

indicate that spiritual intelligence unsignificant effect on employee performance in Islamic banks in Gorontalo Province.

The results of the analysis through multiple regression shows that OCB has a significant effect on employee performance. This implies that OCB is one of the factors that play a role in determining the high or low performance of employees. The higher the OCB, the higher the employee's performance. Conversely, if OCB is low, the employee's performance is also low. This finding also shows that significantly OCB can predict employee performance. These findings also confirm previous research statements that found that OCB was able to improve the ability of colleagues and managers to do their work through more efficient planning, scheduling and problem solving (Muhdar et al. 2015).

In addition, other studies in line with this study include, Khazaei, Khalkhali, and Eslami (2011) found that OCB had a significant effect on employee performance. He explained that two performance components such as technical performance (reflecting requirements and obligations), and content performance (which reflects uncertain activities, such as teams and work protection). These two components, not all are directly related to citizenship performance. Citizenship performance describes behavior that is indirectly connected to task activities, but, for that reason, the texture and organizational, social and psychological protection that is the basis of the facilitator runs the task.

Sugiyanto and Sutanto (2010), OCB is an important factor for the success of tasks related to performance, it is believed that OCB is a social behavior that has more than a formal role carried out by each individual employee. Rastgar et al. (2012), explained that when employees are involved in extra-role behavior, their performance will inherently increase. Without OCB from employees, do not expect employee performance to increase. When employees try harder than before (extra-role behavior), work 
performance will also increase. Harwiki (2013), high OCB, can lead to higher employee performance.

Therefore, managers must empower themselves more to help fellow workers carry out their tasks voluntarily, and apply real positive attitudes, encourage sportsmanship, altruism, conscientiousness, courtesy, and civic virtue of employees. Ekowati, Troena, and Noermijati (2013), said that the higher the OCB, the higher employee performance. He further said that helping behaviour can improve performance, in addition to increasing work productivity and performance stability.

The results showed that correlation spiritual intelligence on employee performance through OCB was positive. This shows that if spiritual intelligence increases, there will be an increase in $\mathrm{OCB}$, and then will also improve employee performance. The results of indirect analysis of spiritual intelligence variables on employee performance variables, showed high consistence with the calculation of the direct effect of spiritual intelligence on OCB. The research results show that spiritual intelligence coefficient on employee performance through OCB is positive. This shows that when spiritual intelligence increases, OCB also increases, and then will also improve employee performance. The results of indirect analysis of the spiritual intelligence variables on employee performance variables, shows consistent results by calculating the direct effects of spiritual intelligence on OCB.

If compared, it can be seen that coefficient of spiritual intelligence on performance of employee through OCB is relatively slightly larger (0.196) when compared to the spiritual intelligence coefficient on employee performance (0.158). So, the link spiritual intelligence with performance is stronger in indirect relationships than direct. So, the results of this study support that spiritual intelligence has a positive relationship with employee performance through OCB as a mediator variable. This is in line with Hanafi (2010) view which suggests that spiritual intelligence has an indirect positive

Economica: Jurnal Ekonomi Islam - Volume 9, Nomor 2 (2018) 
effect on performance with emotional intelligence as a mediator variable. Similarly, the study of Anwar, Osman-Gani, and Osman-Gani (2015) found an indirect relationship between spirituality and employee performance with religion as a mediator variable. Vasconcelos (2009) shows that religion is a broad subject which through principles tends to influence employee behavior, perceptions and decisions. According to Vaughan (2002), if someone gets additional spiritual intelligence every day, they get very good results in their lives. Based on the research above, it is generally understood that spiritual intelligence has good implications on performance when mediated by religious values. This means that the position of religiosity has an important role in realizing OCB.

\section{Conclusions}

Based on the results and discussions described earlier, it can be concluded as follows:

1. Spiritual intelligence shows positive and significant effect on organizational citizenship behavior (OCB) of Sharia Banks in Gorontalo Province. This finding shows that spiritual intelligence of significantly predicts organizational citizenship behavior. It is hinted anyway that spiritual intelligence is one factor that has an important role in determining the level of OCB. The better the spiritual intelligence of an employee, then the better OCB. Conversely, if the employee's spiritual intelligence is low, the prediction will also decrease OCB.

2. Spiritual intelligence shows unsignificant effect on Sharia Banks employee performance in Gorontalo Province, so that high or low spiritual intelligence will not have direct effect for employee performance if it is not mediated by religious values.

3. Organizational citizenship behavior (OCB) shows positive and significant effect on Sharia Banks employee performance in 
The Effects of Spiritual Intelligence and Organizational...

Gorontalo Province. This finding shows that OCB significantly predicts employee performance. It is hinted anyway that OCB has an important role in determining the high and low of employee's performance. The higher the OCB of an employee, the higher the performance. Conversely, if the employee OCB is low, it will certainly reduce the employee performance of concerned.

4. Spiritual intelligence has positive and significant effect on employee performance through organizational citizenship behavior (OCB) variable. This means that the better spiritual intelligence, the better OCB and ultimately improve employee performance. Conversely, the lower the level of spiritual intelligence, the lower OCB will be and ultimately the employee's performance is not optimal.

\section{References}

Anwar, Md. Aftab, AAhad M. Osman-Gani, and AAhad M. Osman-Gani. 2015. "The Effects of Spiritual Intelligence and Its Dimensions on Organizational Citizenship Behaviour." Journal of Industrial Engineering and Management 8 (4): 1162-78. https://doi.org/10.3926/jiem.1451.

Becker, Thomas E., Robert S. Billings, Daniel M. Eveleth, and Nicole L. Gilbert. 1996. "Foci and Bases of Employee Commitment: Implications for Job Performance." Academy of Management Journal 39 (2): 464-82. https://doi.org/10.5465/256788.

Berman, Evan M., and Evan M. Berman. 2006. Performance and Productivity in Public and Nonprofit Organizations. M.E. Sharpe, Inc.

Campbell, John P., Jefrey J. McHenry, and Lauress L. Wise. 1990. "Modeling Job Performance in a Population of Jobs." Personnel Psychology 43 (2): 313-575. https://doi.org/10.1111/j.1744-6570.1990.tb01561.x.

Chahal, Hardeep, and Shivani Mehta. 2010. “Antecedents and Consequences of Organizational Citizenship Behaviour (OCB): A Conceptual Framework in Reference to Health Care Sector." Journal of Services Research 10 (2): 25.

Economica: Jurnal Ekonomi Islam - Volume 9, Nomor 2 (2018) 
Muhdar HM

Doostar, Mohammad, Mehrdad Godarzvand Chegini, and Sita Pourabbasi. 2012. "Survey of Relationship between Spiritual Intelligence and Organizational Citizenship Behavior." Interdisciplinary Journal of Contemporary Research in Business 3 (11): 54.

Ekowati, Vivin Maharani, Eka Afnan Troena, and Noermijati Noermijati. 2013. “Organizational Citizenship Behavior Role in Mediating the Effect of Transformational Leadership, Job Satisfaction on Employee Performance: Studies in PT Bank Syariah Mandiri Malang East Java." International Journal of Business and Management 8 (17): p1. https://doi.org/10.5539/ijbm.v8n17p1.

Emmons, Robert A. 2000a. "Is Spirituality an Intelligence? Motivation, Cognition, and the Psychology of Ultimate Concern." International Journal for the Psychology of Religion 10 (1): 3-26. https://doi.org/10.1207/S15327582IJPR1001_2.

___ 2000b. "Spirituality and Intelligence: Problems and Prospects." International Journal for the Psychology of Religion 10 (1): 57-64. https://doi.org/10.1207/S15327582IJPR1001_6.

—_—. 2003. The Psychology of Ultimate Concerns: Motivation and Spirituality in Personality. Guilford Press.

Fatahi, M. 2007. "Investigated the Impacts of Spirituality at Workplace on the Organizational Citizenship Behavior and Its Relationship with the Faithfulness of the Customer and the Quality of Services in the Iranian Social Security Organization." Tehran University.

Hanafi, Rustam. 2010. "Spiritual Intelligence, Emotional Intelligence And Auditor's Performance." Jurnal Akuntansi Dan Auditing Indonesia 14 (1): 29-40. https://journal.uii.ac.id/JAAI/article/view/2244.

Harwiki, Wiwiek. 2013. "Influence of Servant Leadership to Motivation, Organization Culture, Organizational Citizenship Behavior (OCB), and Employee's Performance in Outstanding Cooperatives East Java Province, Indonesia." IOSR Journal of Business and Management (IOSRJBM) 8 (5): 50-58. https://doi.org/10.9790/487X-0855058.

Javanmard, Habibollah. 2012. "The Impact of Spirituality on Work Performance." Indian Journal of Science and Technology 5 (1): 196166. https://doi.org/10.17485/IJST/2012/V5I1/30966.

Khazaei, K, A Khalkhali, and N Eslami. 2011. "Relationship Between Organizational Citizenship Behavior and Performance of School 
Teachers in West of Mazandaran Province." World Applied Sciences Journal 13 324-30. https://pdfs.semanticscholar.org/4343/b2bd3b5ec664bf936d415db 495beaecfd7ee.pdf.

King, David B., and Teresa L. DeCicco. 2009. "A Viable Model and Self-Report Measure of Spiritual Intelligence." International Journal of $\begin{array}{lllll}\text { Transpersonal } & \text { Studies } & 28 & \text { (1): } & \text { 68-85. }\end{array}$ https://doi.org/10.24972/ijts.2009.28.1.68.

Konovsky, Mary A., and S. Douglas Pugh. 1994. "Citizenship Behavior and Social Exchange." Academy of Management Journal 37 (3): 656-69. https://doi.org/10.5465/256704.

Kumar, T., and S. Pragadeeswaran. 2011. "Effects of Occupational Stress on Spiritual Quotient Among Executives." International Journal of Trade, Economics and Finance 2 (4). http://www.ijtef.org/papers/119F544.pdf.

Mathis, Robert L., and Jackson John H. 2006. Manajemen Sumber Daya Manusia. 10th ed. Jakarta: Salemba Empat.

McGhee, Peter, and Patricia Grant. 2008. "Spirituality and Ethical Behaviour in the Workplace: Wishful Thinking or Authentic Reality." EJBO Electronic Journal of Business Ethics and Organization Studies. https://jyx.jyu.fi/handle/123456789/25429.

Miller, Lisa, Priya Wickramaratne, Marc J. Gameroff, Mia Sage, Craig E. Tenke, and Myrna M. Weissman. 2012. "Religiosity and Major Depression in Adults at High Risk: A Ten-Year Prospective Study." American Journal $\begin{array}{llll}\text { of } & \text { Psychiatry } & 169 & \text { 89-94. }\end{array}$ https://doi.org/10.1176/appi.ajp.2011.10121823.

Muhdar, H.M. 2015. Organizational Citizenshib Behavior of Perusahaan. Gorontalo: Amai Press.

Muhdar, H.M., Mahlia Muis, Ria Mardiana Yusuf, and Nurjannah Hamid. 2015. "The Influence of Spiritual Intelligence, Leadership, and Organizational Culture on Organizational Citizenship Behavior and Employees Performance (A Study on Islamic Banks in Makassar, South Sulawesi Province, Indonesia)." The International Journal of Business \& Management 3 (1). www.theijbm.com.

Nunnally, J. C., and I. H. Bernstein. 1994. Psychometric Theory (3rd Ed.). New York, NY: McGraw-Hill, Inc.

Economica: Jurnal Ekonomi Islam - Volume 9, Nomor 2 (2018) 
Muhdar HM

Organ, Dennis W. 1988. Organizational Citizenship Behavior: The Good Soldier Syndrome. Lexington, MA: Lexington Books.

Otoritas Jasa Keuangan Republik Indonesia. 2017. "Statistik Perbankan Syariah." Jakarta.

Podsakoff, Nathan P., Steven W. Whiting, Philip M. Podsakoff, and Brian D. Blume. 2009. "Individual- and Organizational-Level Consequences of Organizational Citizenship Behaviors: A Meta-Analysis." Journal of $\begin{array}{llll}\text { Applied } & \text { Psychology } & 94 & \text { (1): }\end{array}$ https://doi.org/10.1037/a0013079.

Podsakoff, P M, M Ahearne, and S B MacKenzie. 1997. “Organizational Citizenship Behavior and the Quantity and Quality of Work Group Performance." The Journal of Applied Psychology 82 (2): 262-70. http://www.ncbi.nlm.nih.gov/pubmed/9109284.

Rafferty, Alannah E, and Mark A Griffin. 2004. "Dimensions of Transformational Leadership: Conceptual and Empirical Extensions." The Leadership Quarterly 15 (3): 329-54. https://doi.org/10.1016/j.leaqua.2004.02.009.

Rashvand, Omid, and Elham Bahrevar. 2013. "A Study of the Relationship among Spiritual Intelligence, Organizational Citizenship Behavior and Turnover Intentions." International Journal of Research in Organizational Behavior and Human Resource Management 1 (2): 2534. www.aijsh.org.

Rastgar, A. A., A. Zarei, S. M. M. Davoudi, and K. Fartash. 2012. “The Link between Workplace Spirituality, Organizational Citizenship Behavior and Job Performance in Iran." Arth Prabhand: A Journal of Economics and Management 1 (1).

Robbins, Stephen P. 2008. Perilaku Organisasi. Ed.12., Cet.1. Jakarta: Salemba Empat.

Sugiyanto, Sugiyanto, and Hery Sutanto. 2010. “Membangun Etos Kerja Yang Proaktif Guna, Mengoptimalkan Kinerja Melalui Spiritual Centered Leadership, Employee Empowerment, Organizational Citizenship Behavior." Buletin Ekonomi. http://repository.upnyk.ac.id/2432/1/Giyanto_sri_susilo082011juli.p df.

Tisler, Len, Jerry Biberman, and Robert McKeage. 2002. "Linking Emotional Intellegence, Spirituality and Workplace Performance: Definitions, 
Models and Ideas for Research." Journal of Managerial Psychology 17 (3): 203-18.

Vares, Tiina. 2009. "Reading the 'Sexy Oldie': Gender, Age(Ing) and Embodiment." Sexualities 12 (4): 503-24. https://doi.org/10.1177/1363460709105716.

Vasconcelos, Anselmo Ferreira. 2009. "Intuition, Prayer, and Managerial Decision-making Processes: A Religion-based Framework." Management Decision 47 (6): 930-49. https://doi.org/10.1108/00251740910966668.

Vaughan, Frances. 2002. “What Is Spiritual Intelligence?" Journal of Humanistic Psychology $42 \quad$ (2): $16-33$. https://doi.org/10.1177/0022167802422003.

Yadav, Priyanka, and B.K. Punia. 2016. "Emotionality Does but Spirituality Does Not: The Effect of Emotional and Spiritual Intelligence on Organisational Citizenship Behaviour." Asia-Pacific Journal of Management Research and Innovation 12 (1): 46-55. https://doi.org/10.1177/2319510X16650058.

Yadav, Priyanka, and B K Punia. 2013. "Organisational Citizenship Behavior : A Review of Antecedent, Correlates, Outcomes and Future Research Directions." IJHPD 2 (2). http://www.novapdf.com/.

Zohar, Danah, and I. N. Marshall. 2001. SQ: Connecting with Our Spiritual Intelligence. Bloomsbury. 
